\title{
Editorial
}

\section{C-Journal of Carbon Research: 300th Publications Milestone}

\author{
Craig E. Banks 1,*(D) and Jandro L. Abot 2,*(D) \\ 1 Faculty of Science and Engineering, Manchester Metropolitan University, Manchester M15 6BH, UK \\ 2 Department of Mechanical Engineering, The Catholic University of America, Washington, DC 20064, USA \\ * Correspondence: c.banks@mmu.ac.uk (C.E.B); abot@cua.edu (J.L.A.)
}

Citation: Banks, C.E.; Abot, J.L. C-Journal of Carbon Research: 300th Publications Milestone. C 2021, 7, 24. https://doi.org/10.3390/c7010024

Received: 10 February 2021 Accepted: 10 February 2021 Published: 20 February 2021

Publisher's Note: MDPI stays neutral with regard to jurisdictional claims in published maps and institutional affiliations.

Copyright: (c) 2021 by the authors. Licensee MDPI, Basel, Switzerland. This article is an open access article distributed under the terms and conditions of the Creative Commons Attribution (CC BY) license (https:// creativecommons.org/licenses/by/ $4.0 /)$.
The C-Journal of Carbon Research (ISSN 2311-5629) is quite pleased to announce the publication of its 300th article. This milestone is achieved thanks to the support of scientists around the world who have trusted C-Journal of Carbon Research to publish their highquality research work. We are very appreciative to the authors and recognize their trust considering the many publications options available at this time. The field of carbon research is ever growing, and we will continue to expand into new areas. We look forward to the next milestone and to always increasing the quality of the papers [1-6] at C-Journal of Carbon Research including the publication of timely Special Issues.

Currently, the following Special Issues are open for submission:

- "3D Structure Carbon Materials" (https://www.mdpi.com/journal/carbon/special_ issues/3D_structure_carbon_materials)

- "Carbon-Based Electrochemical Devices" (https://www.mdpi.com/journal/carbon/ special_issues/carbon_electrochemical_devices)

- "Graphene and Carbon Quantum Dots and Related 2D Quantum Dots" (https:/ / www. mdpi.com/journal/carbon/special_issues/carbon_dots_and_related_van_der_waals_ nanostructures)

- "Carbide-Derived Carbons" (https://www.mdpi.com/journal/carbon/special_issues/ carbide_derived_carbons)

- "Carbon-Related Nanomaterials in Analytical Nanoscience and Nanotechnology" (https://www.mdpi.com/journal/carbon/special_issues/nanocarbons_in_analytical_ science)

- "Carbon and Beyond for Sustainable Energy" (https://www.mdpi.com/journal/ carbon/special_issues/carbon_beyond_for_sustainable_energy)

- "Batteries: The New Frontier for Carbon Materials" (https:/ /www.mdpi.com/journal/ carbon/special_issues/batteries_frontier_carbons)

- "Young Carbon Scientists" (https://www.mdpi.com/journal/carbon/special_issues/ young_carbon_scientists)

Furthermore, C-Journal of Carbon Research has recently established several Topical Collections:

- "Carbon-Based Materials for Hydrogen Production, Storage and Conversion" (https: //www.mdpi.com/journal/carbon/special_issues/carbons_for_hydrogen)

- "Carbon-Derived Materials from Bioresources for Advanced Applications" (https: //www.mdpi.com/journal/carbon/special_issues/carbon_derived_materials)

- " $\mathrm{CO}_{2}$ Electrochemical Reduction and Conversion" (https://www.mdpi.com/journal/ carbon/special_issues/carbon_dioxide_electro_reduction_conversion)

- "Feature Papers in the Science and Engineering of Carbons" (https://www.mdpi. com/journal/carbon/special_issues/feature_papers_carbons) 


\section{References}

1. Bokobza, L.; Bruneel, J.-L.; Couzi, M. Raman Spectra of Carbon-Based Materials (from Graphite to Carbon Black) and of Some Silicone Composites. C 2015, 1, 77-94. [CrossRef]

2. Sciortino, A.; Cannizzo, A.; Messina, F. Carbon Nanodots: A Review-From the Current Understanding of the Fundamental Photophysics to the Full Control of the Optical Response. C 2018, 4, 67. [CrossRef]

3. Contescu, C.I.; Adhikari, S.P.; Gallego, N.C.; Evans, N.D.; Biss, B.E. Activated Carbons Derived from High-Temperature Pyrolysis of Lignocellulosic Biomass. C 2018, 4, 51. [CrossRef]

4. Davies, T.J.; Tummino, J.J. High-Performance Vanadium Redox Flow Batteries with Graphite Felt Electrodes. C 2018,4 , 8. [CrossRef]

5. Shrestha, L.K.; Thapa, M.; Shrestha, R.G.; Maji, S.; Pradhananga, R.R.; Ariga, K. Rice Husk-Derived High Surface Area Nanoporous Carbon Materials with Excellent Iodine and Methylene Blue Adsorption Properties. C 2019, 5, 10. [CrossRef]

6. Puech, P.; Kandara, M.; Paredes, G.; Moulin, L.; Weiss-Hortala, E.; Kundu, A.; Ratel-Ramond, N.; Plewa, J.-M.; Pellenq, R.; Monthioux, M. Analyzing the Raman Spectra of Graphenic Carbon Materials from Kerogens to Nanotubes: What Type of Information Can Be Extracted from Defect Bands? C 2019, 5, 69. [CrossRef] 